\title{
Relation between Customer Interaction and Service innovation in Brazil firms: Investigating Organization Learning from Customers
}

\author{
Mohsin Rasheed ${ }^{\mathrm{a}}$, Liu Jianhuab* \\ $a, b$ Zhengzhou University - China
}

\section{A R T I C L E I N F O}

\section{Article history:}

Received on: 06 January 2022

Revised on: 13 January 2022

Accepted on: 21 January 2022

Published on: 03 February 2022

\section{Keywords:}

Baron and Kenny

Customer interaction

Customer value creation

Organization learning

Service innovation

\section{A B S T R A C T}

The main agenda of this study is to evaluate the mediating and secondary effect of customer satisfaction and service innovation, from an organization learning perception a survey is developed in Brazil using a new data set of 190 service firms from Rio Grande do Su, State of Mato Grosso, State of Goias, State of Sao Paulo and State of Bahia. The study used cross-sectional assessment design to collect primary data from individual services firms in the states of Brazil. Data was analyzed with Statistical Package for the Social Science (SPSS). Results indicate that partial mediation was supported by adopting Baron and Kenny method and sobel test. The research is the first attempt to examine the customer interaction practice of service firms in an emerging market of Brazil. In addition, the atmosphere of innovation will regulate the positive relationship between customer firm interaction and organizational learning. Secondly by analyzing the relationship between organizational learning and innovation performance. Thirdly it is revealed that customer firm interaction can positively promote service innovation performance by influencing the improvement of organizational learning.

Copyright (C) 2021 iRAPA International Journal of Business Studies. Published by International Research and Publishing Academy - Pakistan. This is an open access article licensed under CC BY: (https://creativecommons.org/licenses/by/4.0)

\section{Introduction}

The study objective is to validate the mediating effect of service innovation, service customization and organization learning. The research was carried out in micro and small service companies in Brazil. Service innovation has usually been considered a major element in organizational growth and strategies. However, in the past, the research on innovation mainly focused on technological innovation, while the emphasis on service innovation in the service sector was far from enough. (Alam, 2002) In the context of the rapid development of the service industry, service innovation has become an area that has attracted much attention from the business community and academia in the past 10 years. There is no unified understanding of these issues in the field of innovation management and service management research (Serafim, 2021).

Scholars at least agree that the service has some of the characteristics that determine the service innovation is different from technological innovation in manufacturing, it needs to be treated differently (Aas, 2011) The output of service innovation is the integration of service concepts, customer interaction, service delivery systems, and technology choices. As a result, service innovation is to a large extent a series of customer-centric activities whose

\footnotetext{
Engineering, Zhengzhou University - China

E-mail addresses: aim.progressive@gmail.com

DOI: https://doi.org/10.48112/iijbs.v2i1.116

Copyright (C) 2021 iRAPA International Journal of Business Studies

Published by International Research and Publishing Academy

This is an open access article licensed under CC BY

(https://creativecommons.org/licenses/by/4.0)
}

* Corresponding author: Liu Jianhuab, Department of Management

\section{How to cite:}

Rasheed, M., \& Jianhua, L. (2021). Relation between Customer Interaction and Service Innovation in Brazil Firms: Investigating Organization Learning from Customers . iRAPA International Journal of Business Studies, 2(1), 27-34. https://doi.org/10.48112/iijbs.v2i1.116 
purpose is to meet the current and potential needs of customers by creating new services. However, this demand is often an intangible experience, which is difficult for customers to express accurately and clearly. As a result, companies often have deviations when they use traditional market research methods to collect new service information, which may lead to innovation failure. Therefore, some learning people began to pay attention to how to play the role of customers in the development stage of new products (services), such as using development technologies such as lead users and toolboxes (L, 2010).

An empirical study of customer-enterprise interaction in the new service development (NSD) process found that in the service concept development and business analysis stages. Customer participation in the development can help improve the success rate of enterprise service innovation (M, 2007) Summarizing the previous literature on the relationship between customers and service innovation, it was found that most scholars included customers in service innovation projects or new service development processes, that is, customers and innovation teams "co-developed" and inspected customers in this direct role in service innovation. However, few scholars have studied the impact of customer interaction on service innovation in the process of service provision, and they lack the perspective of learning from customers to explore the internal logical relationship between the two. The characteristics of the service industry determine that service production is a process of interaction between service providers and customers (I, 2014).

It is even more lacking from the perspective of learning from customers to explore the internal logical relationship. The characteristics of the service industry determine that service production is a process of interaction between service providers and customers, in which customer participation is indispensable for enterprises to complete the service process. In particular, Customer feedback is essential benefit for companies in context of service customization. Companies learn from their customers on the basis of customer's feedback they usually upgrade their products and services.

As per previous studies in the manufacturing industry, Author focused in service innovation and customer interaction. It shows how innovation effect brand loyalty in mobile phones in Brazil. Results shows there has huge impact of innovation on brand loyalty and customer satisfaction (Magnusson, 2003).

From the perspective of learning, customer firm interaction broadens the channels for enterprises to engage knowledge, increases the ways and opportunities for learning knowledge, which helps to boost organizational learning. Customer firm interaction reflects the degree of customer participation in the process of service production and also enhanced the company's service strategy, and believed that the strategic positioning of the service company reflects a certain degree of differentiation in customer interaction. The actual result after the implementation of this kind of corporate strategy is the customer firm interaction in service (Tether, 2003).

In this study, the customer-firm interaction is divided into the following three dimensions: cooperative production, customer contact, and service customization.
Among them, cooperative production reflects the level of effort that customers put in the service production process. Customers in the service system are not all passive receivers and bystanders. In the service description, certain links are actively completed by customers. In these scenarios, the boundaries of service companies expand and customers act as "cooperative Producers" are emotionally more willing to actively participate in service production, which leads to closer customer interactions (Jaworski, 1993).

Another study shows that front-line employee has more critical in the service industry. In this research author apply a theoretical model for find the innovation aspect and find the motivation in engaging employees. From the perspective of service operation management, the service process can be divided into foreground operations and background operations. The former refers to activities in which customers directly participate, during which customers form a perception of service quality; while the latter refers to the parts that customers cannot see during the service process. Increased customer contact means more face-to-face opportunities between customers and companies, which may lead to more uncertainty. Service customization reflects the degree of personalizing of customer needs in the service process that is, whether customers require companies to provide standardized services or customized services (Matthing, Sandén, \& Edvardsson, 2004).

In the case of the standardized model, the degree of customer-enterprise interaction is low. Service customization is based on the cognition of the individual needs of customers, and more emphasis is placed on the interaction between customers and enterprises. In this case, the degree of interaction is higher, and higher requirements are placed on the ability of enterprises to adapt to changes in demand. To sum up, this study will discuss how customer-firm interactions influence the path of service innovation performance through organizational learning, and reveal the indirect effects of customers on service innovation. For the sake of intuition, the research framework is given first, as shown in Figure 1.

In the past researches (Jaworski, 1993) Shown his research how many manufacturing organizations focused on service innovation by adding some uniqueness and found many challenges during the working hours from product centered to customer orientated services. They also identified the main micro-foundations, which form the basis of positive rearrangement of an organization's dynamic capabilities, so as to achieve an improved with service innovation activities.

In this research author research about intellectual property especially in innovation service firms and since the concept of organizational learning emerged, many scholars have studied it from different perspectives. From the perspective of process (Kindström \& Kowalkowski, 2013) Some scholars understand organizational learning as an input and output process of the organization, and various process models or theories have emerged. Other researchers, from the perspective of ability believe that organizational learning is based on experience or cognition, which is the ability of an enterprise to acquire, share, and utilize knowledge. However, regarded organizational learning as a resource. It is not difficult to see that the research of the latter two perspectives are al 
carried out from the perspective of the role of organizational learning in the organization.

This research focuses on the impact of customerenterprise interaction on organizational learning in the context of the service industry of Brazil. Therefore, using (Serafim \& Veríssimo, 2021) Point of view, organizational learning tends to be defined from a process perspective. Organizational learning is the process of developing new knowledge. This information may affect organizational behaviour. In this process, the members of the organization act as learning agents, transforming personal knowledge into organizational knowledge In order to cope with the uncertainty caused by customers that often appear in the service production process, various functional departments and employees of the enterprise are more likely to realize the value of learning and generate the willingness to learn, so as to search for, obtain and use the implicit knowledge in the service process.

As per previous studies author research on innovation impact on banking sector with the help of organization learning. When a customer appears in the service production process as a co-producer, it can be observed as an input element of the enterprise. Another study shows that the service innovation in a banking sector where the role of business environment in terms of dynamism and competitiveness the customer becomes a "part of the employee" of the enterprise, and the role of the customer occurs Partial changes (Serafim \& Veríssimo, 2021).

In the process of customer interaction, customer capabilities, the knowledge and skills that customers have, the desire to learn and experiment and their ability to participate in activities. The more customers participate in cooperative production, the more likely they are to think that their efforts will pay to service quality, self-value, and satisfaction, especially when they can bring greater benefits to themselves. As a result, active participation in cooperative production has led to the evolution of the customer's own role, which has led to emotional active participation of customers, promoted the development of customer capabilities, and customers are more willing to share their knowledge with service providers.

Hypothesis 1a under the customer interaction scenario, cooperative production facilitates the organization to learn from customers. Customer contact and organizational learning in the service production system, customers often evaluate the entire service production based on the front desk work they actually come into contact with and the perceived service quality. Research of innovative services in the prism of digitization and digitization of information, review of types of innovations and identification of varieties of innovative services by criteria. The increase in operations in direct contact with customers has a significant impact on the entire service production and delivery system. With the increase in the degree of contact, the service process of the enterprise is more exposed to the range that customers can directly perceive, and the customer may inject more uncertainty into the production process (Nemati, 2010) In order to ensure the production efficiency and the effectiveness of the service delivery system, service companies must learn to adjust the technical level and personnel skills in service production at any time.
Previous studies shows, investigating the corporate social responsibility and financial performance of the organization with mediating role of financial compatibility and author used to apply Sobel test. A series of regression analyses were used to identify the proposed hypotheses. We obtained two remarkable conclusions. Uncertainty from customers forces companies to be able to discover changes in the environment, identify the opportunities and challenges these changes bring to the company, propose solutions and make wise choices or decisions, and continue to feedback, improve and adjust the program during implementation, Spreading good experience and practices from a local or small area to a wider area and scope for sharing, these all reflect the ability of an organization to change or redesign itself to adapt to the changing environment (Santos-Vijande, López Sánchez, \& Rudd, 2016).

At the same time, with the increase in customer contact, service companies as innovators can obtain more valuable knowledge and information through wider channels, including knowledge formed on-site by customers "learning", customer complaints about defects in service technology, and service Inefficient management, etc. Through the "learning process" knowledge is continuously accumulated on the basis of individual practical actions, and learning activities are enhanced from the individual level to the organizational level. Therefore, the following hypotheses are proposed:

Hypothesis $1 \mathrm{~b}$ in the context of customer interaction, the higher the level of customer contact, the more conducive the organization to learn from customers. Service customization and organizational learning in the context of the service economy, increasingly diversified and personalized needs of customers continue to emerge. Therefore, providing customized services can bring higher customer satisfaction. Customization is considered as a competitive means of differentiation strategy. This strategy allows customers to have more choices that accept standardized services or put forward customized requirements.

Since the production, purchase, and consumption of services generally occur in the same process. Customers have changes in their needs during the process of purchasing and consuming services, the front desk staff of the company will inevitably be required to respond promptly, requiring employees to have more only the flexibility and strong judgment can meet the individual needs of customers. Through the continuous accumulation of practical experience, the company's insight and judgment ability have been improved, so that it can take targeted actions on changes from customers.

In the past process, this type of customer knowledge is more unclear than tangible product knowledge, and it is difficult for customers to make clear descriptions and accurate feedback. Therefore, traditional market research methods are often incapable of obtaining customer potential demand information. However, the individualized demands put forward by customers in the process of participating in the service production. Externalized expression of knowledge helps to reduce the ambiguity of knowledge, and promotes the conversion of tacit knowledge to explicit knowledge. Therefore, the following hypotheses are proposed: 
Hypothesis $1 \mathrm{C}$ in the context of customer-enterprise interaction, service customization is conducive to promoting the organization to learn from customers.

Innovation atmosphere has a direct promotion effect on organizational learning behaviour, the indirect influence of the innovation atmosphere on organizational learning has not yet attracted enough attention. An innovative organizational atmosphere means that the organization advocates active innovative ideas and communication, and the organization provides corresponding resources to support the implementation of innovative ideas (Xie, Guan, \& Lin, 2020) In the case of a high innovation atmosphere, on the one hand, in the process of service production and delivery, front-line service employees are exaggerated by the innovation atmosphere and often try to solve the same problems in the service process in different ways.

Customers are the main source of their innovative ideas. If they want to pursue innovative ideas, they will inevitably pay more attention to valuable customer knowledge. In other words, these employees will actively acquire knowledge from the customer-enterprise interaction process and share them internally. Intentionally On the other hand, managers encourage all parts of the organization (employees, work teams, functional departments) to pay more attention to customer knowledge by encouraging employees' creativity and rewarding "customer-oriented" innovations. Therefore, customer-enterprise interaction is easier to play a role in promoting organizational learning. On the contrary, in the case of a low innovation atmosphere, organizations often lack motivation to conceive new ideas, and cannot provide corresponding innovation support (Cadwallader, Jarvis, Bitner, \& Ostrom, 2010) and respond insufficiently to external stimuli (such as customer-induced uncertainty, demand changes) sensitive. In this way, organizations cannot grasp and make full use of the learning opportunities provided by customers. The accumulation of knowledge is mainly carried out through passive learning or unconscious "learning by doing". Customer-enterprise interaction obviously promote the improvement of organizational learning. Therefore, the improvement of the innovation atmosphere is conducive to enhancing the promoting effect of customer-enterprise interaction on organizational learning. Therefore, the following hypotheses are put forward:

Hypothesis 2 Assume that the innovation atmosphere will regulate A cooperative production; B customer contact; $\mathrm{C}$ the positive relationship between service customization and organizational learning, that is, if the innovation atmosphere improves, it will be easier to play the role of customer-firm interaction for organizational learning the promotion effect.

Innovation, as a source of maintaining competitive advantage, relies on the knowledge, experience, and skills of individuals and collectives in the organization. STATA (Feng \& Ma, 2020) found that organizational learning can lead to innovation, especially in knowledge-intensive industries, where the learning of individuals and organizations guides innovation and becomes the only source of sustainable competitive advantage in the organization. The resource-based enterprise theory believes that an enterprise is a collection of various resources, and its unique resources that are difficult to imitate are the main source of supporting its competitive advantage (Candelin-Palmqvist, Sandberg, \& Mylly, 2012). These resources help enterprises Provide products or services of higher quality than competitors. In the new economic era, knowledge is regarded as the most strategically valuable resource for enterprises. Many scholars point out that the only important resource in the innovation process is knowledge. In the process of customer-enterprise interaction, organizational learning helps to strengthen the knowledge base of the enterprise, and then promotes the service innovation of the service enterprise from three aspects: 1. the timely acquisition of knowledge about service defects and business models from customers is conducive to improvement.

The efficiency of service production and delivery, thereby reducing costs and improving the financial performance of the organization; 2. Enhanced the willingness of enterprises to develop new services and the ability to achieve new innovative combinations, shortening the development cycle of new services, so as to be faster than competitors the development of new services at a rapid pace will help maintain and enhance the market's competitive position and open up new market opportunities (Djellal \& Gallouj, 2016). By acquiring knowledge about the current and potential needs of customers, companies can accurately improve or develop "marketable "Service, retain customers and improve customer perception of service excellence, and help companies attract new customers (Woo, Kim, \& Wang, 2021) therefore, the following hypotheses are put forward: Hypothesis 3 Organizational learning in the process of service interaction is beneficial to the improvement of service innovation performance. To sum up, this study will discuss how customer-firm interactions influence the path of service innovation performance through organizational learning, and reveal the indirect effects of customers on service innovation. For the sake of intuition, the research framework is given first, as shown in Figure 1.

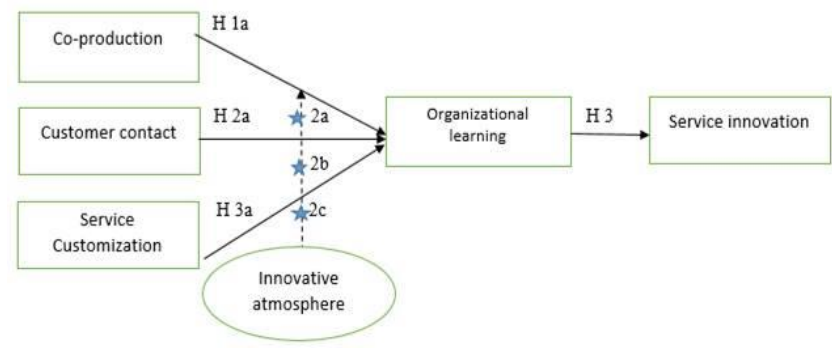

Fig. 1. Theoretical Framework

\section{Material \& Methods}

From August to October 2020, 231 service companies in the five provinces of Brazil were randomly selected for questionnaire survey, and 193 copies were returned, of which 188 were valid questionnaires, and the valid questionnaire rate was 87.8 per cent. The valid questionnaire covers 7 service sectors: healthcare (43), tourism (31), finance (18), real estate (37), logistics and transportation (16), consulting (41) and telecommunications (4). Before the large-scale survey, three service companies were selected for pre-survey in Brazil. In table 1 shows the respondent profiles of my collective my. Most of the respondents were Director and 
high-level managers in the company (among them about 1 stew and 3 are CEO or COO, and about 2 stew and 3 are department managers). In order to avoid the problem of deviation from the unreformed questionnaires, this study compared the recovered 193 valid questionnaires with the 5 invalid questionnaires.

Table 1

Sample profile of respondent

\begin{tabular}{cccc}
\hline Variable & Item & Frequency & Percentage \\
\hline \multirow{3}{*}{ Designation } & Director & 34 & 47 \\
& Manager & 42 & 54 \\
& Executive & 19 & 67 \\
Years of & Others & 21 & 25 \\
employment & Less than 3 & 23 & 76 \\
& 3 to 10 years & 36 & 83 \\
Number of & Over 10 years & 16 & 21 \\
Employees & Less than 50 & 87 & 53 \\
& 50 to 200 & 76 & 92 \\
\hline
\end{tabular}

\section{Variable Measurement}

Baron and Kenny (1986) method is the most commonly used method of testing mediation. According to Social Citation Index it is also called as a classical test of mediation. It has remained a popular method of testing mediation for over two decades. In majority of the studies, Baron \& Kenny (1986) method has been used (Rucker, Preacher, Tormala \& Petty, 2011; MacKinnon, Fairchild \& Fritz, 2007).

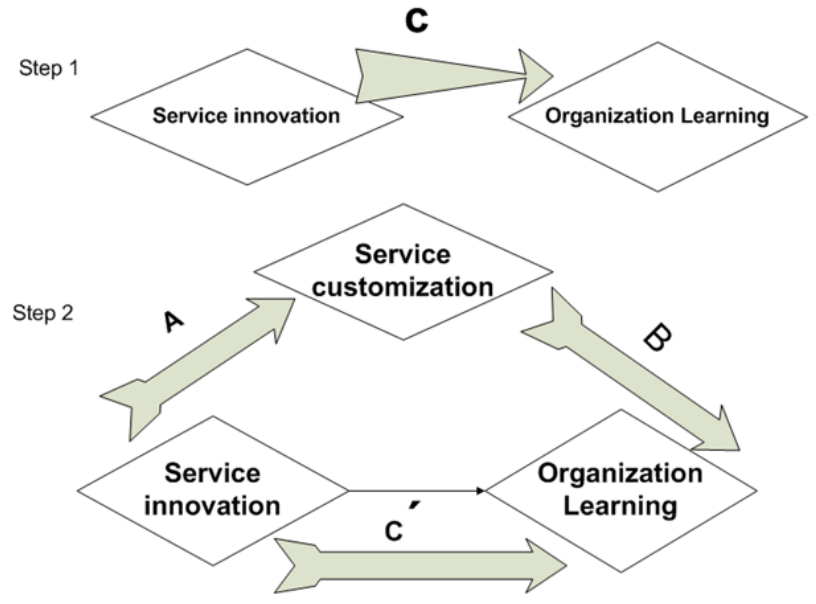

Fig. 2. Baron \& Kenny

Theoretical model of the mediating effect of service customization on the associations of service innovation and organization learning. (a) The associations of service innovation, organization learning and service customization (b) the correlation of service customization with organization learning after controlling for the predictor variable; (c) the correlations among service innovation with organization learning:, (c') the correlations among Service innovation and organization learning after adding service customization.
In order to ensure the validity and reliability of the measurement tool, this research mainly adopts the existing literature at home and abroad in terms of the operational definition and measurement method of concepts such as customer interaction, organizational learning, innovation atmosphere, and innovation performance. The scales that have been used can be appropriately adjusted according to the purpose of the research and used as a tool for collecting empirical data. The customer-enterprise interaction scale was adapted (Liu, Gan, Luo, \& Zhang, 2017).

In order to control the impact of other variables on organizational learning and service innovation performance, based on previous studies, the following five control variables were selected: firm size, industry, ownership type, market competition intensity, and government intervention. Among them, the size of the enterprise adopts the number of full-time employees in the enterprise, and the data is processed logarithmic ally, and the remaining 4 are counted as dummy variables.

\section{Results \& Discussion}

\section{Descriptive Analysis}

Using SPSS statistical analysis software, using multiple regression, Boron and Kenny test and hierarchical regression analysis to verify the research hypothesis. Table 2 lists the verification results of Hypothesis $1 \mathrm{a} \sim 1 \mathrm{c}$ and Hypothesis 3. The results show that cooperative production, customer contact, and service customization in the process of service interaction each have a significant positive impact on organizational learning $(\mathrm{p}<0.01)$. At the same time, just as the hypothesis put forward, organizational learning also has a significant role in promoting service innovation performance $(\mathrm{b}=$ $0.60, \mathrm{p}<0.001)$, therefore, hypotheses $1 \mathrm{a} \sim 1 \mathrm{c}$ and hypotheses 3 have been verified.

\section{Table 2}

Multiple regression analysis of customer firm interaction, organizing leaning and service innovation performance

\begin{tabular}{ccc}
\hline Variable & Model 1 & Model 2 \\
\hline Control variable & & \\
Constant & 4.27 & 0.37 \\
Industry & 0.14 & 0.03 \\
Scale & 0.08 & 0.13 \\
Competitive intensity & 0.23 & 0.27 \\
Degree of government intervention & -0.27 & 0.30 \\
Independent Variable & & \\
Co-production & 0 & 0.15 \\
Customer contact & 0.19 & 0.11 \\
Service customization & 0.25 & 00 \\
Organization learning & 0 & 0.60 \\
F value & 13.59 & 12.64 \\
R square & 0.32 & 0.30 \\
Adj R square & 0.32 & 0.31 \\
Note: $*{ }^{*} \mathrm{p}<0.1, * * \mathrm{p}<0.05, \mathrm{p}<.001, \mathrm{~N}=190$ & \\
\hline
\end{tabular}

\section{Mediation Analysis}

The mediator variable was tested to investigate its effect of service customization. In this research PLS analysis is tested through a software. The major advantage of PLS 
has ability to handle multi collinearity among independents and has edge of handling the missing data and improving the predictions. PLS analysis has two major benefits, firstly measurement of reliability and co relation between the hypothesized variables. The overall $R$ square value obtained states that service innovation, service customization and organization learning together explain 62 per cent $(R$ square $=0.622)$. The mediation effect is further examined on the basis of Soble's test.

Table 3

\begin{tabular}{cccc} 
Sobel test applied & & & \\
\hline Independent Variable & Mediating variable & $\mathbf{Z}$ & P-value \\
\hline Organization Learning & Service innovation & 0.7145 & 0.6534 \\
Service Innovation & Service Customization & 0.631 & 0.670 \\
Co-Production & Service Customization & 0.527 & 0.654 \\
\multicolumn{2}{c}{ Notes : ${ }^{*} \mathrm{p}<0.1,{ }^{* *} \mathrm{p}<0.05, \mathrm{p}<.001, \mathrm{~N}=190$} & \\
\hline
\end{tabular}

According to the Sobel test, it acted as a mediator between service innovation and service customization at the 99 confidence interval, and as a partial mediator between Service customization and organization learning at the 99 confidence interval. Third, the co-production showed significant mediating effects on the relationship between service customization, when analysed using Baron and Kenny's three-step analysis, and acted as an intermediary for high-user and administrative levels at 99.9 confirmed intervals, according to Sobel's test.

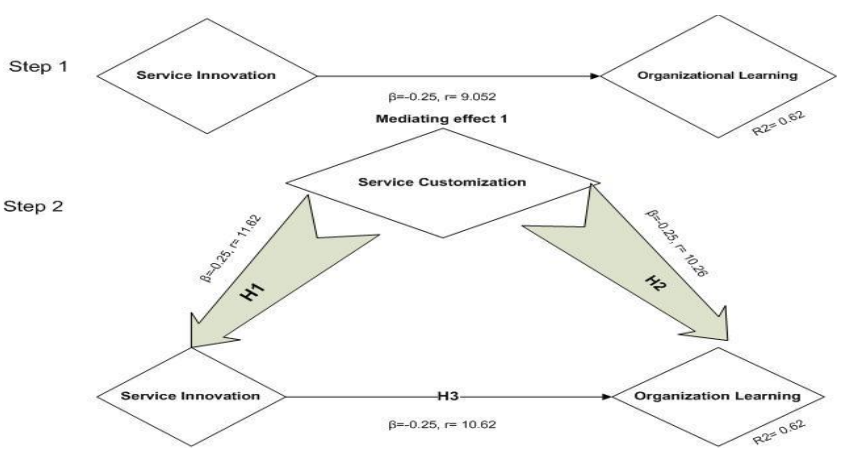

Fig. 3. Mediation Analysis

\section{Reliability Analysis}

An internal reliability analysis was carryout in this research, individually for the items of each independent variables and dependent variables by using the SPSS reliability method. Alpha value is greater than 0.7 as show in Table 3, the alpha values of reliability analysis for this study ranges from 0.712 to 0.911 . From the results obtained, all the alpha values are greater than 0.7 . Thus it can be concluded that this instrument has internal reliability and is therefore reliable ( $\mathrm{Mu}$, Bossink, \& Vinig, 2019).
Table 4

The Reliability analysis result

\begin{tabular}{cccc}
\hline Variable & No of Item & Mean & Alpha \\
\hline Organization learning & 7 & 4.837 & 0.734 \\
Service innovation & 6 & 5.242 & 0.712 \\
Service customization & 7 & 4.131 & 0.870 \\
Co-production & 6 & 4.272 & 0.654 \\
Degree of government & 7 & 6.301 & 0.564 \\
intervention & 8 & 5.112 & 0.911 \\
Customer contact & 7 & & \\
Service Innovation Strategy & 7.526 & 0.760 \\
\hline
\end{tabular}

\section{Hypothesis Testing}

The hierarchical regression method and Baron and Kenny (1986) mediating method was also used to verify hypotheses 2a 2c. The first step is to let the control variable enter the regression equation, the second step is to add the independent variable (cooperative production, customer contact, service customization, innovation atmosphere), and the third step is to add the product of the independent variable and the adjustment variable (cooperative production innovation atmosphere, Customer contact innovation atmosphere, service customization innovation atmosphere), and the results of regression analysis are shown in Table 4 . It can be seen that the innovation climate regulates the positive relationship between cooperative production and organizational learning $(b=0.18,0.19, p<0.05)$, and also regulates the relationship between service customization and organizational learning $(b=0.13,0.15, p<0.01)$, hypothesis $2 \mathrm{a}$ and hypothesis $2 \mathrm{c}$ pass the verification. However, the innovation climate has no significant moderating effect on the relationship between customer contact and organizational learning. Therefore, Hypothesis $2 \mathrm{~b}$ fails the verification. The organization learning is shown to significantly influence the service innovation in the first regression equation. Organization learning is shown to significantly influence the service customization in the second regression equation. Innovative atmosphere must significantly influence the dependent variable in third equation. Here, the organization learning and service customization are entered as predictors. 
Table 5

\begin{tabular}{|c|c|c|c|}
\hline Variable & Model 3 & Model 4 & Model 5 \\
\hline \multicolumn{4}{|l|}{ Control variable } \\
\hline Constant & 4.36 & 4.51 & 4.72 \\
\hline Industry & 0.38 & 0.34 & 0.37 \\
\hline Scale & 0.08 & 0.07 & 0.8 \\
\hline Type of ownership & 0.17 & 0.11 & 0.19 \\
\hline Degree of government intervention & 0.25 & 0.18 & 0.22 \\
\hline \multicolumn{4}{|l|}{ Independent Variable } \\
\hline \multicolumn{4}{|l|}{ Co-production } \\
\hline Customer contact & 0.19 & 0.15 & 0.19 \\
\hline Service customization & 0.19 & 0.11 & 0.18 \\
\hline Organization learning & 0.25 & 0.20 & 0.19 \\
\hline \multirow{2}{*}{$\begin{array}{l}\text { Co-production * Innovative } \\
\text { atmosphere }\end{array}$} & 0.29 & 0.29 & 0.23 \\
\hline & 0 & 0.18 & 0.19 \\
\hline $\begin{array}{l}\text { Customer Exposure * Innovative } \\
\text { atmosphere }\end{array}$ & 0 & 0.21 & 0.25 \\
\hline \multirow{2}{*}{$\begin{array}{l}\text { Customized Services * Innovative } \\
\text { atmosphere }\end{array}$} & 0 & 0.13 & 0.15 \\
\hline & 20.47 & 21.64 & 22.21 \\
\hline F value & 0.622 & 0.704 & 0.82 \\
\hline $\mathrm{R}$ square & 0.592 & 0.673 & 0.723 \\
\hline Adj R square & 0.277 & 0.081 & 0.342 \\
\hline \multicolumn{4}{|l|}{ Change Value } \\
\hline $\begin{array}{c}\text { Note:** The dependent variable is } \\
\text { organization learning }\end{array}$ & & & \\
\hline
\end{tabular}

\section{Discussion}

This study explored the mediation and indirect analysis and impact of customer firm interaction on organizational learning, and whether organizational learning will promote the theoretical issues of corporate service innovation performance. The results show that customer firm interaction has a positive promotion effect on organizational learning, and this promotion effect may be regulated by the organizational innovation atmosphere, and organizational learning can bring higher service innovation performance. Baron and Kenny and Sobel test method has been used to find the mediating effect, although there are many research literatures on organizational learning and innovation performance in the past, few scholars have investigated the impact of customer firm relationship on organizational learning and innovation performance from the perspective of service production process. Therefore, the conclusions of this research have some implications for existing research literature expanded.

In the service process, the degree of customer contact or service customization has increased, bringing more uncertainty to the enterprise. In order to cope with uncertainty, similarly if a company cannot keep up with changes in customers, it will also be eliminated from the market. The pressure brought by customers penetrates to the individual level and the organizational level, allowing companies to realize the value of learning from customers, thereby driving individual organizations to actively learn. This also verifies the findings (Rekettye $\&$ Boxer, 2011) that external pressures come to a higher learning motivation. At the same time, the demand information delivered by customers in the service process reduces the testiness of customer knowledge. Which helps knowledge transfer from customers to enterprises.
Service innovation performance, which has a better enlightenment for enterprises to carry out service innovation. The management should start to improve the situation of organizational learning from two aspects: Firstly establish the concept of "learning from customers", through service process design, allow customers to participate more in the service process, and actively create opportunities to learn from customers (Jankelová, Skorková, Joniaková, \& Némethová, 2021) Secondly organize an atmosphere of innovation, encourage employees to seek innovation, incorporate employee learning behaviour into the evaluation system, and urge the company to realize the value of learning, and actively grasp the opportunity to learn from customers with an open mind.

\section{Conclusion}

This research starts from the features of the service industry, established on the perspective of organizational learning, and proposes a research framework for the relationship between customer-firm interaction and service innovation performance. The questionnaire survey to verify the proposed research hypothesis. The conclusions of the empirical research and after testing Sobel test \& Baron and Kenny test can be summarized into the following two points: Firstly In the context of customer firm interaction, cooperative production is conducive to the makeover of customer roles and the full use of customer capabilities, thereby promoting organizational learning; customer contact and service customization will increase the service production process. Uncertainty pressure from customers has become the driving force for organizational learning. At the same time, the three dimensions broaden the channels for organizations to learn from customers, which is conducive to the improvement of organizational learning. In addition, the atmosphere of innovation will regulate the positive relationship between customer-firm interaction and organizational learning, Secondly by analysing the relationship between organizational learning and innovation performance, it is revealed that customer-enterprise interaction can positively promote service innovation performance by influencing the improvement of organizational learning. This finding helps people understand customers more deeply the promotion of enterprise service innovation.

This study has several limitations, each of which opens additional opportunities for future study. First, as per survey the customer contact and service customization according to customer will increase the production process.it is revealed that customer interaction can positively promote service innovation performance by influencing the improvement of organizational learning. (Irianto, Natalisa, \& Rodiyah, 2020)

Therefore, future studies could enlarge the sample size to include more firms from other cities and regions. It provides an important starting point for future intention and organization learning to enhance service innovation.

\section{References}

Aas, T. P. (2011). The impact of service innovation on firm-level financial performance. The Service Industries Journal, 2071-2090. 
Alam, I. (2002). An Exploratory Investigation of User Involvement in New Service Development. Journal of the Academy of Marketing Science, 250261.

Cadwallader, S., Jarvis, C., Bitner, M., \& Ostrom. (2010). Frontline employee motivation to participate in service innovation implementation. . Journal of the Academy of Marketing Science, 38.

Candelin-Palmqvist, H., Sandberg, B., \& Mylly, U. (2012). Intellectual property rights in innovation management research. A review. Tecnovation, 502-512.

Djellal, F., \& Gallouj, F. (2016). Paths for Greening Through Service Innovation. Sustainability, 187-215.

Feng, C., \& Ma, R. (2020). Identification of the factors that influence service innovation in manufacturing enterprises by using the fuzzy DEMATEL method. Journal of Cleaner Production , 253.

I, P. F. (2014). Capitalism impact on health management model in Brazil. Rev UNINGÁ Rev (Online) , 5.

Irianto, J., Natalisa, D., \& Rodiyah. (2020). Public Service Innovation and the Diffusion of Innovation in Indonesia. Sustainability, 13.

Jankelová, N., Skorková, Z., Joniaková, Z., \& Némethová, I. (2021). A Diverse Organizational Culture and Its Impacton Innovative Work Behavior of Municipal Employees. Sustainability, 13.

Jaworski, B. (1993). Market Orientation: Antecedents and Consequences. Journal of Marketing, 53-71.

Kindström, D., \& Kowalkowski. (2013). nabling service innovation: A dynamic capabilities approach. . Journal of Business Research.

L, B. M. (2010;). How to stop customers from fixating on price. Harv Bus Rev, 84-91.

Liu, C., Gan, B., Luo, N., \& Zhang, Y. (2017). Clarifying the effect of organization learning on service innovation: the mediating role of intellectual capital. . The International Journal of Human Resource Management, 1-28.

M, S. (2007). The myth of commoditization. MIT Sloan Manage Rev, 10-4.

Magnusson, P. (2003). Benefits of Involving Users in Service Innovation. European Journal of Innovation Management, 228-233.

Matthing, J., Sandén, B., \& Edvardsson, B. (2004). New Service Development: Learning from and with Customers. International Journal of Service Industry Management- , 479-498.

Mu, Y., Bossink, B., \& Vinig, T. (2019). Service innovation quality in healthcare: service innovativeness and organizational renewal as driving forces. Total Quality Management and Business Excellence , 1219-1234.

Nemati, A. (2010). Impact of Innovation on Customer Satisfaction and Brand Loyalty, A Study of Mobile Phones users in china 2010. journal of business research .

Rekettye, G., \& Boxer, I. (2011). The relation between perceived service innovation, service value, emotional intelligence, customer commitment and loyalty in b2b. International Journal of Services and Operations Management, 222-256.

Santos-Vijande, M., López Sánchez, J., \& Rudd, J. (2016). Frontline employees' collaboration in industrial service innovation: routes of co-creation's effects on new service performance. . Journal of the Academy of Marketing Science, 350-375.

Serafim, G. H. (2021). The Relationship between Strategic Orientation, Service Innovation, and Performance in Hotels in Angola. Sustainability, 13(2071-1050), 16. doi: $10.3390 /$ su 13116256
Serafim, G., \& Veríssimo, C. (2021). The Relationship between Strategic Orientation, Service Innovation, and Performance in Hotels in Angola. Sustainability, 12.

Tether, B. (2003). The sources and aims of innovation in services: Variety between and453 within sectors. Economics of Innovation and New Technology, 481505.

Woo, H., Kim, S., \& Wang, H. (2021). Understanding the role of service innovation behavior on business customer performance and loyalty. . Industrial Marketing Management, 41-45.

Xie, L., Guan, X., \& Lin, X. (2020). Triad collaboration of hotel employers, employees and customers for service innovation in a changing world. Journal of Hospitality and Tourism Management, 10-18. 